PhD Kasper Sipowicz, https:/ / orcid.org/0000-0001-7384-2899

Department of Interdisciplinary Disability Studies

The Maria Grzegorzewska University in Warsaw

M.A. Marlena Podlecka, https://orcid.org/0000-0002-2213-374X

Department of Neuroses, Personality Disorders and Eating Disorders

Institute of Psychiatry and Neurology in Warsaw

Prof. IPiN, PhD Tadeusz Pietras, https:/ / orcid.org/0000-0003-1771-3819

The Second Department of Psychiatry

Institute of Psychiatry and Neurology in Warsaw

\title{
Logotherapy - an attempt to establish a new dialogue with one's own life
}

\section{Logoterapia - próba nawiązania nowego dialogu z własnym życiem}

\author{
https://doi.org/10.34766/fetr.v46i2.811
}

\begin{abstract}
The paper deals with one of the schools of psychotherapy, namely the so-called logotherapy. This term comes from the Greek word logos - meaning. Therapy with the meaning of life - because we might call logotherapy so in other words - was developed by Viktor E. Frankl in the first half of the 20th century. That Vienna psychiatrist pointed out rightly that the greatest problem of the modern man is the inability to make sense in life, which gives rise to many mental disorders. In the paper we attempt to approximate both the theoretical assumptions of logotherapy and its practical application in work with the patient.

Keywords: logotherapy, existential analysis, Viktor E. Frankl, psychotherapy, mental disorders, psychiatry.

Abstrakt: Niniejszy artykuł traktuje o jednej ze szkół psychoterapii, a mianowicie tzw. logoterapii. Owa nazwa pochodzi od greckiego logos, czyli sens. Terapia sensem życia - bo tak inaczej możemy nazwać logoterapię - została opracowana przez Viktora E. Frankla w I poł. XX w. Ów wiedeński psychiatra słusznie zauważył, że największym problem współczesnego człowieka jest dojmujący brak sensu $\mathrm{w}$ życiu, który stanowi przyczynę wielu zaburzeń psychicznych. W artykule staramy się przybliżyć zarówno założenia teoretyczne logoterapii, jak i jej praktyczne zastosowanie w pracy $\mathrm{z}$ pacjentem.
\end{abstract}

Słowa kluczowe: logoterapia, analiza egzystencjalna, Viktor E. Frankl, psychoterapia, choroby psychiczne, psychiatria.

\section{Introduction}

Currently, depression is the most commonly diagnosed mental disorder (Lukas, 2011; Orzechowska, Gałecki, Pietras, 2017). The majority of patients with such diagnosis complains of lack of sense in life that they feel, which, in extreme cases, can lead to suicidal attempts (Gałecki, Szulc, 2018; Butcher, Hooley, Mineka, 2018; Ruczaj, 2020). As early as the first half of the twentieth century, this was noted by an Austrian psychiatrist, Viktor E. Frankl (2019). 
That observation prompted him to develop the foundations of a new school of psychotherapy - logotherapy (from the Greek word logos - meaning). The doctor assumed that the man demonstrates an immanent need for meaning. For the sake of accuracy, it should be added that previous psychoanalytic concepts presupposed the domination of the need (principle) of pleasure (S. Freud, 2021), or the need for power (Adler, 2016). Frankl (2018a) linked a feeling of sense in life to a feeling of responsibility for one's own life.

\section{Man in the globalized world - from homo sapiens to homo patients}

The contemporary world, permeated by the spirit of existential and moral nihilism (Nietzsche, 2017; Cioran, 2007) reinforces the need for pleasure in humans. That pleasure can be obtained by the acquisition of further material goods, professional success or casual sexual encounters. The mass media promote and perpetuate such a worldview (Stanisławczyk, 2015). If the individuals are not able to satisfy the need for pleasure, they often look for substitutes in the form of stimulants - alcohol and drugs (Ryś, 2017; Sipowicz, Pietras, 2017). The relentless rush for worldly goods causes the loss of the value that is fundamental for everyone - to love and to be loved (Ryś, Greszta, Herring, 2020). The mental condition of an individual is undoubtedly influenced also by the working environment. We live in the times of so-called financial capitalism, which is characterized by the fact that accumulation of capital is more profitable than production (Piketty, 2015a, 2015b). Such state of affairs results in the already wealthy getting richer and richer, and further pauperization of the poor, resulting in increasing social stratification. Already in 1891, The Holy Father Leo XIII stated in his Encyclical Rerum Novarum:

"That the spirit of revolutionary change, which has long been disturbing the nations of the world, should have passed beyond the sphere of politics and made its influence felt in the cognate sphere of practical economics is not surprising. The elements of the conflict now raging are unmistakable, in the vast expansion of industrial pursuits and the marvellous discoveries of science; in the changed relations between masters and workmen; in the enormous fortunes of some few individuals, and the utter poverty of the masses; the increased self-reliance and closer mutual combination of the working classes; as also, finally, in the prevailing moral degeneracy"1.

Many workers are employed on the basis of civil law contracts, which, depending on the legislation of the country concerned, deprives them of the right to free health care and a pension. Ipso facto they experience the uncertainty of tomorrow, which is why they are referred to as the precariat (Standing, 2014; Urbański, 2014; Therborn, 2015). Therefore, the modern man experiences a discrepancy between his own (and other people's) expectations

${ }^{1}$ http://www.vatican.va/content/leo-xiii/en/encyclicals/documents/hf_l-xiii_enc_15051891_rerumnovarum.html (access: 12.02.2021). 
concerning their life and the reality, in which they happen to live. The inability to satisfy the ever-increasing needs can lead to frustration, which is the cause of many mental disorders (Mori, 2020). Thus, the modern man is a suffering man. The suffering is especially severe for those who have lost their moral backbone in the form of professed values. Most schools of psychotherapy are based on nihilistic philosophy. Thus, the patient, whose cause of suffering is the ubiquitous nihilism, professed also by himself, is subjected to nihilism-based psychotherapy [sic!]. This peculiar paradox was noticed by Frankl (2019), who stated:

"The existential vacuum which is the mass neurosis of the present time can be described as a private and personal form of nihilism; for nihilism can be defined as the contention that being has no meaning. As for psychotherapy, however, it will never be able to cope with this state of affairs on a mass scale if it does not keep itself free from the impact and influence of the contemporary trends of a nihilistic philosophy; otherwise it represents a symptom of the mass neurosis rather than its possible cure. Psychotherapy would not only reflect a nihilistic philosophy but also, even though unwillingly and unwittingly, transmit to the patient what is actually a caricature rather than a true picture of man" (ibidem, p. 191).

In addition, that psychiatrist emphasizes that the modern school programs perpetuate young people's belief that they are merely passive puppets led by biological and psychological instincts (ibid.). Of course, genetic or environmental conditions matter, but this does not deprive the man of his free will and choice. For many people, a mental illness provides a convenient excuse to reject the responsibility for their lives and behavior. This prompted Frankl to create a new psychotherapeutic school, the so-called Third Viennese School of Psychotherapy.

\section{Theoretical assumptions of logotherapy}

As already mentioned, the modern man represents a demanding attitude towards the world. Frankl (2019) reverses this perspective by saying: “(...) it does not matter what we expect from life, but what life expects of us" (ibidem, p.124). Thus, the man ceases to be a kind of passive actor directed by fate, because he regains responsibility for his life. For a believer, God, and for a non-believer, the fate or destiny sends us various problems and concerns. Our role is to find the optimal solutions based on values. It is values, not needs, that motivate our lives (Frankl, 2018b). Therefore, Frankl (2019) opposes the idea that homeostasis should be maintained for mental hygiene and contrasts it with the so-called noodynamics theory (Greek nóos - mind, reason), in which each person is expected to fulfill a particular meaning. For the sake of accuracy, it should be added that, over the course of life, the sense of life evolves. According to Frankl, the sense of life can be discovered by:

- creative work or activity;

- experiencing something or contact with another individual; 
- the way in which we endure the inevitable suffering (ibidem, p. 167).

The first way is to find the meaning in work, and therefore through particular professional achievements. The second one - through love. However, the above does not mean sex, which without love often becomes a desperate attempt to fill the existential void, but the highest form of intimacy with another person. It can be a love for either one's spouse and children, or one's parents or other relatives or friends. For love is the most precious gift we can offer to others. As St. John Paul II (1991) stated it in his Encyclical Centesimus Annus:

"When man does not recognize in himself and in others the value and grandeur of the human person, he effectively deprives himself of the possibility of benefitting from his humanity and of entering into that relationship of solidarity and communion with others for which God created him. Indeed, it is through the free gift of self that man truly finds himself. This gift is made possible by the human person's essential "capacity for transcendence". Man cannot give himself to a purely human plan for reality, to an abstract ideal or to a false utopia. As a person, he can give himself to another person or to other persons, and ultimately to God, who is the author of his being and who alone can fully accept his gift. A man is alienated if he refuses to transcend himself and to live the experience of self-giving and of the formation of an authentic human community oriented towards his final destiny, which is God. A society is alienated if its forms of social organization, production and consumption make it more difficult to offer this gift of self and to establish this solidarity between people" 2 .

The meaning of life can also be found through suffering. However, this should not be misunderstood. Frankl makes a reservation that suffering should be avoided if possible. However, there are times when this is impossible. Such situations include the death of the next of kin, or a serious illness. Frankl (2019) noted that "in some way, suffering ceases to be suffering at the moment it finds a meaning, such as the meaning of a sacrifice" (ibidem, p. 170). Suffering should not be regarded as guilt or punishment for sins, but as a task set for us by God (fate/destiny). It is important to approach this challenge in a fully responsible manner. In logotherapy, responsibility is defined as responding to values, i.e. implementation of the professed values and responsibility for the consequences of such values (Suchocka, 2011).

In addition, it should be added that logotherapy - unlike other schools of psychotherapy - does not show retrospective inclinations, directing the patient's attention towards the present and future. Thus, the client does not return to the often traumatic events and experiences of the past, on which the therapists working in the psychodynamic current

${ }^{2}$ http://www.vatican.va/content/john-paul-ii/en/encyclicals/documents/hf_jpii_enc_01051991_centesimus-annus.html (access: 15.02.2021). 
base. Therefore, logotherapy can be regarded as a method that carries a positive, even optimistic, message (cf. Frankl, 1984, 2017, 2018a, 2018b, 2019).

Another important element of Frankl's theory is the recognition of the phenomenon of freedom. In the postmodernism age in which we live, the issue of individual freedom is constantly being raised. These slogans are obviously correct, but they are often distorted. Freedom cannot be an exemption from responsibility for one's choices and values in life. Ipso facto we should talk about "freedom to" and not "freedom from". Indeed, the rejection of traditional moral values, and therefore freedom from values, led to the creation of two totalitarian systems in the 20th century (Fromm, 2015; Arendt, 2014). Barbara Stanisławczyk (2015), writing about contemporary moral relativism, points to the oddity that every moral judgment of the behavior of another person is considered per se as a manifestation of intolerance. A situation in which any behavior (if not criminalized) is permissible and acceptable by the society promotes the feeling of existential void.

\section{Therapeutic techniques used in logotherapy}

Many of the therapeutic techniques used in logotherapy are common with other schools of psychotherapy. Each of the currents of psychotherapy has developed a different terminology of psychotherapeutic interventions. The conceptual ranges of these terms sometimes overlap, or partially overlap at other times. It is therefore impossible to disambiguate these terms. Logotherapy makes use of the following techniques:

- Socratic dialogue - this is a form of conducting a dialogue and asking questions, in which the person asked begins to notice errors in the way he or she reasons. The method was described by Plato (2020) in "Dialogues", where it was attributed to Socrates. Socratic dialogue is the basic method of working with the patient/client in cognitive behavioral therapy (Popiel, Pragłowska, 2008);

- attitude modulation - this is a change in the emotional attitude of the patient towards certain phenomena of social life (Popielski, 2004; Lukas, 2014);

- dereflection - this is a distraction from what the patient is excessively focused on. Frankl (2019) called such exaggerated concentration hyperreflection;

- paradoxical intention - this is a technique used to work with a patient who has socalled anticipatory anxiety. This is a constant fear of negative events that occur in certain situations. The technique is based on the fact that the therapist asks the patient to feel with all his/her might the need for his/her greatest fears coming true. For example, a person who stutters when speaking in public is advised to stutter deliberately. This kind of paradoxical intention causes the patient's speech to be fluent. The paradoxical intention was introduced independently of Frankl by the Milan School of Systemic Family Therapy (Goldenberg, Goldenberg, 2006). In this 
school, however, the paradoxical intention is more focused on the action, and in logotherapy on the creation of a thought construct (Frankl, 2019).

- logodrama (noodrama, psychodrama) is a method of psychotherapy that uses previously prepared scenarios for the patients to play scenes similar to those found literary drama (Bielańska, 2019). The creator of the psychodrama was Jacob Levy Moreno (2019). Most often, after an initial pantomime or choreotherapy, a therapeutic group or a single patient begins a presentation in which they have the task of playing themselves, conducting a monologue, talking to a double which is an embodiment of one's own conscience, swapping roles between patients, working with an empty chair and working with a mirror. The psychodrama ends with a group conversation and discussion. Psychodrama is commonly used by cognitive behavioral therapy, psychodynamic therapy and some of the currents of humanistic therapy e.g. Gestalt (Chu, 2013);

- motivational dialogue - is a conversation conducted by a psychotherapist with the patient/client aimed at increasing internal motivation for changes resulting from the need to solve problems. This method assumes that the patient is able to take part in the change of his/her situation. Motivational dialogue is widely used in cognitivebehavioral therapy, alcohol addiction therapy and social work. Currently, it is one of the basic methods (alongside the harm reduction program) in modern addiction treatment therapy (Rosengren, 2013);

- suggestion - is exerting a real impact on the behavior or thinking of the other person without rational argumentation and without coercion (Czabała, 2021).

It should be added that out of the above techniques dereflection and paradoxical intent are unique to logotherapy (cf. Frankl, 1984, 2017, 2018a, 2018b, 2019; Lukas, Schönfeld, 2015).

\section{Conclusion}

Logotherapy seems to be aimed at modern existential human problems of the early 21st century. From this point of view, it reaches to the most mature and at the same time the most intimate dilemmas in the structure of personality. It is the only one of the psychotherapeutic currents to take into account the spiritual aspect of the man close to his dilemmas inducing existential anxiety. Therefore, one can be tempted to state boldly that logotherapy has the characteristics of a field integrating different currents and psychotherapeutic schools in the optics of the deep spirituality of man. Many psychotherapy trends (e.g. the psychodynamic current) treat the sense of life and the values only as a mock reaction and defense mechanisms (A. Freud, 2021; Frankl, 2018). In contrast, Frankl (1984, 
2017, 2018a, 2018b, 2019) made the meaning of life and the values a fundamental substrate for therapeutic work.

\section{Bibliography:}

Adler, A. (2016). Understanding life [in Polish], Cracow: Wydawnictwo vis-à-vis/Etiuda.

Arendt, H. (2014). The roots of totalitarianism [in Polish], Warsaw: Wydawnictwo Świat Książki.

Bielańska, A. (ed.) (2019). Psychodrama. Elements of theory and practice [in Polish], Warsaw: Wydawnictwo Eneteia.

Butcher, J.N., Hooley, J.M., Mineka, S. (2018). Abnormal Psychology [in Polish], Sopot: Gdańskie Wydawnictwo Psychologiczne.

Chu, V. (2013)., Gestalt Psychotherapy [in Polish], Łódź: Wydawnictwo Od Do.

Cioran, E. (2007). On the heights of despair [in Polish], Warsaw: Wydawnictwo Aletheia.

Czabała, J.Cz. (2021). Therapeutic factors in psychotherapy [in Polish], Warsaw: Wydawnictwo Naukowe PWN.

Frankl, V.E. (1984). Homo Patiens [in Polish], Warsaw: Instytut Wydawniczy Pax.

Frankl, V.E. (2017). The Doctor and the Soul [in Polish], Warsaw: Wydawnictwo Czarna Owca.

Frankl, V.E. (2018a). The Will to Meaning: Foundations and Applications of Logotherapy [in Polish], Warsaw: Wydawnictwo Czarna Owca.

Frankl, V.E. (2018b). Hidden God. In the search of the ultimate meaning. [in Polish], Warsaw: Wydawnictwo Czarna Owca.

Frankl, V.E. (2019). Man's Search for Meaning [in Polish], Warsaw: Wydawnictwo Czarna Owca.

Freud, A. (2021). The Ego and the Mechanisms of Defence [in Polish], Warsaw: Wydawnictwo Naukowe PWN.

Freud, S. (2021). Beyond the Pleasure Principle [in Polish], Warsaw: Wydawnictwo Naukowe PWN.

Fromm, E. (2015). Escape from Freedom [in Polish], Warsaw: Spółdzielnia Wydawnicza Czytelnik.

Gałecki, P., Szulc, A. (2018). Psychiatry [in Polish], Wrocław: Edra Urban \& Partner.

Goldenberg, H., Goldenberg, I. (2006). Family Therapy: An Overview [in Polish], Cracow: Wydawnictwo Uniwersytetu Jagiellońskiego.

St. John Paul II, (1991). Encyclical Centesimus Annus, http://www.vatican.va/content/johnpaul-ii/en/encyclicals/documents/hf_jp-ii_enc_01051991_centesimus-annus.html) (access: 15.02.2021).

Leo XIII, (1891). Encyclical Rerum Novarum, (http://www.vatican.va/content/leoxiii/en/encyclicals/documents/hf_l-xiii_enc_15051891_rerum-novarum.html) (access: 12.02.2021). 
Lukas, E. (2011). Wertfülle und Lebensfreude. Logotherapie bei Depressionen und Sinnkrisen, Munich/Vienna: Profil Verlag.

Lukas, E. (2014). Lehrbuch der Logotherapie. Menschenbild und Methoden, Munich/Vienna: Profil Verlag.

Lukas, E., Schönfeld, H. (2015). Sinnzentrierte Psychotherapie. Die Logotherapie von Viktor

E. Frankl in Theorie und Praxis, Munich/Vienna: Profil Verlag.

Moreno, J.L. (2019). Psychodrama, Princeton: Psychodrama Press.

Mori, H. (2020). Existenzanalyse und Logotherapie, Vienna: Facultas Verlag.

Nietzsche, F. (2017). The Will to Power: An Attempted Transvaluation of All Values [in Polish], Cracow: Wydawnictwo vis-à-vis/Etiuda.

Orzechowska, A., Gałecki P., Pietras T. (ed.) (2017). Recurrent depressive disorders - etiology, diagnosis, therapy [in Polish], Wrocław: Wydawnictwo Continuo.

Piketty, T. (2015a). The economics of inequality [in Polish], Warsaw: Wydawnictwo Krytyki Politycznej.

Piketty, T. (2015b). Capital in the Twenty-First Century [in Polish], Warsaw: Wydawnictwo Krytyki Politycznej.

Platon, (2020). Dialogues [in Polish], Kęty: Wydawnictwo Antyk.

Popiel, A., Pragłowska, E. (2008). Cognitive behavioral psychotherapy [in Polish], Warsaw: Wydawnictwo Paradygmat.

Popielski, K. (2004). Noo-Logotherapy. Introduction elements [in Polish], Lublin/Kielce: Świętokrzyskie Centrum Profilaktyki i Edukacji.

Rosengren, D.B. (2013). Building Motivational Interviewing Skills - A Practitioner Workbook [in Polish], Cracow: Wydawnictwo Uniwersytetu Jagiellońskiego.

Ruczaj, M. (2020). Logotherapy in the context of suicidology: the use of logotheory in the investigation and prevention of suicides, part 1 [in Polish], Kwartalnik Naukowy Fides et Ratio, 4 (44), 322-333.

Ryś, M. (2017). Family with alcohol problem. Functioning of a co-addicted person, Kwartalnik Naukowy Fides et Ratio, 4 (32), 428-453.

Ryś, M., Greszta, E., Śledź, K. (2020). The feeling of being loved and the language of communication of young adults. Kwartalnik Naukowy Fides et Ratio, 2 (42), 47-76.

Sipowicz, K., Pietras, T. (2017). The breakdown of traditional values in the family and the problem of alcohol dependence among young people [in Polish], Kwartalnik Naukowy Fides et Ratio, 3 (31), 48-60.

Standing, G. (2014). The Precariat: The New Dangerous Class [in Polish], Warsaw: Wydawnictwo Naukowe PWN.

Stanisławczyk, B. (2015). Who is afraid of the truth? The fight against Christian civilization in Poland [in Polish], Warsaw: Wydawnictwo Fronda. 
Suchocka, L. (2011). A sense of responsibility in health and illness. Noo-theoretical perspective [in Polish]. Warsaw: Wydawnictwo Difin.

Therborn, G. (2015). The Killing Fields of Inequality. How global inequality is destroying millions of human lives and how to combat it [in Polish]. Warsaw: Wydawnictwo Naukowe PWN.

Urbański, J. (2014). Precariat and a new class struggle. Transformations of the modern working class and its forms of struggle [in Polish]. Warsaw: Instytut Wydawniczy Książka i Prasa. 